\title{
Community-Based Adaptation: Challenge and Opportunity in Indonesia
}

\author{
Anis Qomariah ${ }^{1 *}$, Hartuti Purnaweni ${ }^{1,2}$, and Sudarno Utomo ${ }^{1,3}$ \\ ${ }^{1}$ Master Program of Environmental Science, School of Postgraduate, Universitas Diponegoro \\ ${ }^{2}$ Department of Public Administration, Faculty of Social and Political Science, Universitas \\ Diponegoro \\ ${ }^{3}$ Department of Environmental Engineering, Faculty of Engineering, Universitas Diponegoro
}

\begin{abstract}
Climate change is a serious problem mostly caused by human activities but the impacts are felt by all creatures in the word. These conditions are worsened by the rise of 'dirty industries' that exceed the environmental carrying capacity. Many studies had showed that people need to do something to cut climate change from individual to state scale. Therefore, community plays an important role to climate change program's success. It is known as community-based adaptation (CBA). CBA combines indigenous knowledge, community needs, and local conditions so the program is more likely to implement. In Indonesia, climate change adaptation and mitigation are run in community level namely ProKlim. Government also gives the best practiced community with title and prizes. This paper aims to identify and synthesize previous researches related to CBA and challenge and opportunity of CBA practices in Indonesia. The findings of this paper are CBA is proven in shaping resilience on disaster management, aquaculture, food, and water. Moreover, indigenous knowledge, local leader, funding, and government involvement are the important instrument of CBA. Despite the numerous reports on CBA succeed, there are still some challenge and opportunity of CBA practices in Indonesia.
\end{abstract}

\section{Introduction}

Climate change is a major problem that significantly affects coral reefs, drought, freshwater resources, agriculture, aquaculture, sea-level rises, wetlands, health, extinction of species, and social and economic life [1-12]. Vulnerable areas such as small islands are more likely affected by the climate change impact $[7,9,13]$. To cope with these problems, adaptation, and mitigation strategies are needed.

Adaptation plans initiated by a formal institution can be more improved by involving the community in the planning process to sync the actual condition and community needs [7]. Adaptation plan requires participation as an essential part of the socio-ecological system [14]. It can be initiated by the community (bottom-up) or formal institutions such as NGOs and government (top-down) $[15,16]$. The adaptation strategy initiated by the community is called

* Corresponding author: anisqomariah99@gmail.com 
community-based adaptation (CBA). CBA is a grassroots-driven, small-scale, place-based method that has synergies with bigger development goals. In theory, CBA's local-scale focus allows for greater recognition and integration of existing indigenous knowledge, capacities, priorities, and context, as well as enabling impacts to be addressed at the scale at which they experience [13]. Community-based adaptation (CBA) is a common policy response in international development, but often encounters implementation and longevity challenges [17].

In Indonesia, CBA performed on the lowest administrative level: RW and village. The community initiatives are then assessed by the Ministry of Environmental and Forestry (MEF). The community initiatives that passed the assessment will get a title from MEF as a Proklim Kampung. It aims to increase community involvement in climate change adaptation and mitigation. Although CBA sounds promising, several studies had shown the barrier to CBA success such as limited funds, human resources, communication, government and institutions, technology, infrastructure, power, and inequality [18, 19]. According to [20], the socio-social setting in Nepal shapes the achievement and disappointment of CBA. Poor people and weak families are reliant upon the higher ranks, elites, and influential people inside the local gatherings for getting profits by the tasks or programs. This paper will discuss the current research on community-based adaptation and challenges and opportunities in Indonesia.

\section{Current research on community-based adaptation}

\subsection{CBA and resilience}

In the previous study, CBA plays an important role to create disaster resilience [7, 21-24], agriculture [2, 11-12, 21, 25], aquaculture [26], food [7], and water [11, 25-28] resilience in the community. Moreover, one of the successful CBA planning processes is comprehensively addressing local socio-ecological factors of vulnerability and resilience, including food security, governance, health and education, and indigenous knowledge [2]. CBA is consistent with SDG's goal to empower the community to build resilience on natural disasters and climate change impact [22]. CBA uses disaster risk management to identify the potential disaster risk and find the best adaptation and mitigation scheme according to their community. In aquaculture, CBA is urgently needed to cope with climate change [26]. Research conducted in the Maheni community shows that water resilience was reached by agreement and restrictions on water use.

\subsection{Indigenous knowledge}

Indigenous knowledge provides insights on how the community dealt with climate change in the past and also what to do in the future [29-31]. Moreover, indigenous knowledge creates an instrumental reason for developing transformation techniques to CBA [23]. Integrating several sources of knowledge and establishing connections between specific sightings can be an effective way to find the best strategy of CBA so it can improve the success of CBA [13, 23]. In the Maharashtra State community in India, indigenous knowledge uses to maintain the sustainable crop system as one of the CBA strategies [21]. In Myemsingh community, they use natural substrate from bamboo, sugarcane, and tree, resulting in a larger number of fish production [21]. To link indigenous knowledge with community-based adaptation strategies, the community needs to understand the situation in the community and communicate with residents in the early stages of decision-making [32]. In Alaska, indigenous knowledge uses as the basis of hazard adaptation and mitigation strategy [29]. 
Research in Bangladesh found that indigenous knowledge is used as a CBA strategy to cope with climate change [33]. Indigenous knowledge combined with science can use as an adaptation strategy in CBA [34].

\subsection{Community leadership}

The previous study has shown that community leaders had an influential ability to succeed in the CBA project. According to [35], community leaders know about social, communication, and personal networks. To simplify, community leaders become a bridge for community members and formal institutions (government, NGO). Furthermore, strong leadership is stated as a key role of CBA success [1].

\subsection{Funding}

Funding plays a key role in CBA implementation [7, 24, 36]. The increasing of funding is urgently needed to support the CBA project [31]. Research in 20 communities in Pacific Islands shows that the locally funded CBA shows better results than internationally funded CBA [13]. It is because locally sponsored programs are more likely to be created and led by people who are familiar with local contexts and socio-cultural nuances. The research on a low-lying island in the Philippines found that not all of the community members received stilted houses due to limited funds [7]. Research conducted by [37] showed that external funding was often needed to support CBA strategies.

\subsection{Government involvement}

Although the CBA process is not mandatory, a community still needs support and share power from the government $[22,38]$. The recent study found that one potential way for tending to administration challenges at the community level is to include a different scope of partners of different scales including government, to catalyst socio-social and institutional change, prompting enhancements in assistance conveyance and comprehensiveness [20]. Government involvement along with NGOs, community-based organizations, and related stakeholders may help the community to plan and implement the CBA strategies [7, 25-26, 39-40]. Moreover, the strength of the specific rhetoric of the international development community and the limited involvement of the government have had negative effects on the strength of decision-making mechanisms at community levels [17].

\section{CBA challenge and opportunity in Indonesia}

Indonesia is one of the countries that put serious attention on climate change and is proactively involved in an international meeting on the environment. It also has an office under the MEF authority that specialized in controlling climate change called DitjenPPI. In CBA, MEF has launched a CBA program in 2016 called Climate Village (ProKlim). This program is fully initiated and designed by the community, so the program fits with the community's needs and local conditions.

\subsection{Challenge}

Unlike the CBA program in another country [7, 13], CBA programs in Indonesia (ProKlim) are often community-funded. Community members will gather some amount of money to 
fund their programs. Due to the limited fund, the community cuts the number of their strategies or swaps it into the low-cost strategy such as recycling. On the other hand, some Proklim strategies may need an infrastructure to support their programs. Research in ProKlim Tangkerang Labuai showed that the lack of infrastructure delayed community member participation [41]. On the other hand, there is not any evaluation and monitoring after the community gets the ProKlim title. This brings out the uncontrolled effects that the community will no longer practice their programs.

Most of Proklim's strategies are held by a group of community members, but since the pandemic of COVID-19 in 2020 some ProKlims are no longer active. To cope with this, the community along with MEF needs to find an alternative strategy at household level.

\subsection{Opportunity}

Some studies about ProKlim in Indonesia had reported that ProKlim has positive impacts on environmental, social, and economic [41-44]. It is reported that ProKlim has succeeded embellish the community environment by their planting flowers and vegetable program. In some areas, the community gets additional funding from their $3 \mathrm{R}$ waste management. ProKlim requires the community to dig their indigenous knowledge, strength, weakness, and their needs. Therefore, ProKlim shapes communities to have a better understanding of their community and resources. From these CBA practices, ProKlim can develop their climate change programs to eco-tourism programs. Furthermore, the community can engage the private company in their CBA program to gain more funding and succeed in their implementation programs.

\section{Conclusion}

Climate change affects all aspects of our lives and changes how we behave and see the world. Climate changes also trigger various disasters such as floods and drought. Small islands are reported to be the most vulnerable area to climate change-related sea-level rises. Communitybased adaptation as a grassroots and indigenous adaptation plays an important role in climate change adaptation. This paper reviews recent research on community-based adaptation and discuss challenge and opportunity in Indonesia. The finding is community-based strategies are proven to build community resilience in disaster management, aquaculture, food, and water. To more engage with the community, indigenous knowledge is often used as one of the community-based adaptation strategies. The local leader also plays an important role to conduct and control the strategy implementation and also as a 'bridge' between community members and formal institutions. Funding is also important for the community to implement and develop their community-based adaptation strategies. Government support is also important since the community often needs support and share power from the government. In Indonesia, community-based adaptation strategies as known as ProKlim under the Ministry of Environmental and Forestry authority. The challenge of ProKlim practices is funding, infrastructure, and social limitation activity because of the COVID-19 pandemic. On the other hand, ProKlim opportunities are a positive impact on the environmental, social, and economic, providing a better understanding for the community member, partnering with a private company and developing their strategy into ecotourism.

\section{References}

1. R. Asugeni, M. Redman-MacLaren, J. Asugeni, T. Esau, F. Timothy, P. Massey, D. MacLaren, A community builds a "bridge": An example of community-led adaptation to 
sea-level rise in East Kwaio, Solomon Islands, Climate and Development, 11(1), 91-96 (2019).

2. B. Basel, G. Goby, J. Johnson, Community-based adaptation to climate change in villages of Western Province, Solomon Islands, Marine Pollution Bulletin, 156, 111266 (2020)

3. O. P. Choko, L. S. Olabisi, R. U. Onyeneke, S. N. Chiemela, L. S. O. Liverpool-Tasie, L. Rivers, A Resilience Approach to Community-Scale Climate Adaptation. Sustainability, 11(11), 3100 (2019)

4. J. D. Ford, M. Sherman, L. Berrang-Ford, A. Llanos, C. Carcamo, S. Harper, S. Lwasa, D. Namanya, T. Marcello, M. Maillet, V. Edge, Preparing for the health impacts of climate change in Indigenous communities: The role of community-based adaptation, Global Environmental Change, 49, 129-139 (2018)

5. N. Hammouri, M. Al-Qinna, M. Salahat, J. Adamowski, S. O. Prasher, Community based adaptation options for climate change impacts on water resources: The case of Jordan, Journal of Water and Land Development, 26(1), 3-17 (2015)

6. T. -F. Hsieh, Y. -M. Lee, Community-Based Adaptation to Climate Change: The Case of a Community University Workshop in Taiwan, Sustainability, 13(4), 1729 (2021)

7. M. L. Jamero, M. Onuki, M. Esteban, N. Tan, Community-based adaptation in low-lying islands in the Philippines: Challenges and lessons learned, Regional Environmental Change, 18(8), 2249-2260 (2018)

8. R. Lasage, S. Muis, C. Sardella, M. van Drunen, P. Verburg, J. Aerts, A Stepwise, Participatory Approach to Design and Implement Community Based Adaptation to Drought in the Peruvian Andes, Sustainability, 7(2), 1742-1773 (2015)

9. M. A. Mycoo, Beyond $1.5^{\circ} \mathrm{C}$ : Vulnerabilities and adaptation strategies for Caribbean Small Island Developing States, Regional Environmental Change, 18(8), 2341-2353 (2018)

10. B. Paterson, A. Charles, Community-based responses to climate hazards: typology and global analysis, Climatic Change, 152, 327-343 (2019)

11. F. A. Shaheen, M. H. Wani, S. A. Wani, C. Norphel, Climate Change Impact in Cold Arid Desert of North-Western Himalaya: Community Based Adaptations and Mitigations, Knowledge Systems of Societies for Adaptation and Mitigation of Impacts of Climate Change, Springer Berlin Heidelberg, 239-256 (2013)

12. P. Suresh, Community based adaptation measures of agriculture system in Himalayan Region of Nepal: A case study of Dhye village, Upper Mustang, Sustainable Water Resources Management, 4(4), 823-832 (2018)

13. K. E. McNamara, R. Clissold, R. Westoby, A. E. Piggott-McKellar, R. Kumar, T. Clarke, F. Namoumou, F. Areki, E. Joseph, O. Warrick, P. D. Nunn, An assessment of communitybased adaptation initiatives in the Pacific Islands, Nature Climate Change, 10(7), 628639 (2020)

14. H. W. Mairomi, J. N. Kimengsi, Community-Based Actors and Participation in Rangeland Management. Lessons from the Western Highlands of Cameroon, Sustainability, 13(4), 1700 (2021)

15. L. C. Hagedoorn, L. M. Brander, P. J. H. van Beukering, H. M. Dijkstra, C. Franco, L. Hughes, I. Gilders, B. Segal, Community-based adaptation to climate change in small island developing states: An analysis of the role of social capital, Climate and Development, 11(8), 723-734 (2019)

16. H. Reid, Ecosystem- and community-based adaptation: Learning from community-based natural resource management, Climate and Development, 8(1), 4-9 (2016)

17. H. M. Barrowman, J. R. A. Butler, Beyond Challenges in Community-Based Adaptation: Critical Insights from the Human Ecology Framework, Human Ecology Review, 26(1), 73-94 (2021) 
18. A. E. Piggott-McKellar, K. E. McNamara, P. D. Nunn, J. E. M. Watson, What are the barriers to successful community-based climate change adaptation? A review of grey literature, Local Environment, 24(4), 374-390 (2019)

19. B. Simane, B. Zaitchik, The Sustainability of Community-Based Adaptation Projects in the Blue Nile Highlands of Ethiopia, Sustainability, 6(7), 4308-4325 (2014)

20. B. R. Regmi, C. Star, W. L. Filho, An overview of the opportunities and challenges of promoting climate change adaptation at the local level: A case study from a community adaptation planning in Nepal, Climatic Change, 138(3-4), 537-550 (2016)

21. B. Adhikari, K. Taylor, Vulnerability and adaptation to climate change: A review of local actions and national policy response, Climate and Development, 4(1), 54-65 (2012)

22. G. Forino, J. von Meding, G. Brewer, Community based initiatives to mainstream climate change adaptation into disaster risk reduction: Evidence from the Hunter Valley (Australia), Local Environment, 24(1), 52-67 (2019)

23. E. Kaján, An integrated methodological framework: Engaging local communities in Arctic tourism development and community-based adaptation, Current Issues in Tourism, 16(3), 286-301 (2013)

24. Saleem Khan, A., Sabuj Kumar, M., Sudhir Chella, R., \& Devdyuti, B. Chennai City and Coastal Hazards: Addressing Community-Based Adaptation Through the Lens of Climate Change and Sea-Level Rise (CBACCS), Springer International Publishing, 777-798 (2020)

25. S. Karki, P. Burton, B. Mackey, Climate change adaptation by subsistence and smallholder farmers: Insights from three agro-ecological regions of Nepal, Cogent Social Sciences, 6(1), 1720555 (2020)

26. N. Ahmed, S. W. Bunting, S. Rahman, C. J. Garforth, Community-based climate change adaptation strategies for integrated prawn-fish-rice farming in Bangladesh to promote social-ecological resilience, Reviews in Aquaculture, 6(1), 20-35 (2014)

27. C. -R. Nguimalet, Comparison of community-based adaptation strategies for droughts and floods in Kenya and the Central African Republic, Water International, 43(2), 183204 (2018)

28. S. A. Rankoana, Climate change impacts on water resources in a rural community in Limpopo province, South Africa: A community-based adaptation to water insecurity, International Journal of Climate Change Strategies and Management, 12(5), 587-598 (2021)

29. R. Bronen, D. Pollock, J. Overbeck, D. Stevens, S. Natali, C. Maio, Usteq: Integrating indigenous knowledge and social and physical sciences to coproduce knowledge and support community-based adaptation, Polar Geography, 43(2-3), 188-205 (2020)

30. R. Clissold, K. E. McNamara, Exploring local perspectives on the performance of a community-based adaptation project on Aniwa, Vanuatu, Climate and Development, 12(5), 457-468 (2020)

31. P. Silwal, L. Roberts, H. G. Rennie, M. J. Lexer, Adapting to climate change: An assessment of local adaptation planning processes in forest-based communities in Nepal, Climate and Development, 11(10), 886-898 (2019)

32. D. Kim, J. E. Kang, Building Consensus with Local Residents in Community-Based Adaptation Planning: The Case of Bansong Pilbongoreum Community in Busan, South Korea, Sustainability, 12(4), 1559 (2020)

33. Md. M. Monwar, Md. G. Mustafa, N. A. Khan, M. S. Hossain, M. M. Hossain, M. K. Majumder, R. M. Chowdhury, M. A. Islam, M. Chowdhury, M. S. Alam, Indigenous Adaptation Practices for the Development of Climate Resilient Ecosystems in the Hail Haor, Bangladesh, Global Social Welfare, 5(2), 125-136 (2018) 
34. B. Iticha, A. Husen, Adaptation to climate change using indigenous weather forecasting systems in Borana pastoralists of southern Ethiopia, Climate and Development, 11(7), 564-573 (2019)

35. N. Keys, D. C. Thomsen, T. F. Smith, Adaptive capacity and climate change: The role of community opinion leaders, Local Environment, 21(4), 432-450 (2016)

36. A. Fenton, D. Gallagher, H. Wright, S. Huq, C. Nyandiga, Up-scaling finance for community-based adaptation, Climate and Development, 6(4), 388-397 (2014)

37. F. Murtinho, H. Eakin, D. López-Carr, T. M. Hayes, Does External Funding Help Adaptation? Evidence from Community-Based Water Management in the Colombian Andes, Environmental Management, 52(5), 1103-1114 (2013)

38. P. Kirkby, C. Williams, S. Huq, Community-based adaptation (CBA): Adding conceptual clarity to the approach, and establishing its principles and challenges, Climate and Development, 10(7), 577-589 (2018)

39. J. S. Gruber, J. L. Rhoades, M. Simpson, L. Stack, L. Yetka, R. Wood, Enhancing climate change adaptation: Strategies for community engagement and university-community partnerships, Journal of Environmental Studies and Sciences, 7(1), 10-24 (2017)

40. M. T. Islam, M. Nursey-Bray, Adaptation to climate change in agriculture in Bangladesh: The role of formal institutions, Journal of Environmental Management, 200, 347-358 (2017)

41. W. Setiawan, Persepsi Masyarakat Terhadap Program Kampung Iklim (Proklim) Kelurahan Tangkerang Labuai Kecamatan Bukit Raya Kota Pekanbaru, Prepotif Jurnal Kesehatan Masyarakat, 3(2), 68-75 (2019)

42. D. Faedlulloh, B. Irawan, R. Prasetyanti, Program unggulan kampung iklim (proklim) berbasis pemberdayaan masyarakat, Publisia: Jurnal Ilmu Administrasi Publik, 4(1), 2844 (2019)

43. N. Y. Ghina, S. Zunariyah, Kampung Iklim: Pengelolaan Lingkungan Berbasis Pemberdayaan Masyarakat, Jurnal Sosiologi DILEMA, 32(2), 80-98 (2017)

44. M. W. Priyanto, J. H. Mulyo, I. Irham, Did The Program Kampung Iklim Lead Farmers to Implement more Adaptation Strategies? Case Study of Rice Farmers in Sleman Regency, Agro Ekonomi, 31(1), (2020) 